Jurnal Ekonomi dan Industri

e-ISSN: $2656-3169$

Volume 21, No.3, September-Desember 2020

p- ISSN: 0853-5248

\title{
PENGARUH PELATIHAN DAN KOMITMEN TERHADAP PRODUKTIVITAS KERJA KARYAWAN PT. JINGGA LANGIT MEDIA
}

\author{
Mentari 1) \\ 1) Mahasiswa Program Studi Manajemen FE UNKRIS \\ Vembra Anandita 2) \\ 2) Dosen Program Studi Manajemen FE UNKRIS \\ Alamat: Kampus UNKRIS, Jatiwaringin Jakarta Timur \\ Email: vembraanandita@gmail.com
}

\begin{abstract}
To determine the effect of training and work commitment on work productivity at PT. Jingga Langit Media. The research method uses qualitative and quantitative descriptive analysis, the analysis model used is linear regression both simply and multiple. The study population of all employees of PT. Jingga Langit Media. This research sampling technique uses census sampling, where all members of the population are sampled. Training and work commitment have a positive and significant effect on work productivity at PT. Jingga Langit Media, both partially and simultaneous.
\end{abstract}

Keywords: Training, work commitment and work productivity

\section{PENDAHULUAN}

Pada zaman yang semakin maju dan dengan melihat persaingan bisnis dewasa ini, perusahaan berusaha semaksimal mungkin untuk meningkatkan kinerja karyawannya, agar produktivitas kerja mereka dapat meningkat. Perusahaan perlu memperhatikan kebutuhan seluruh karyawan sehingga karyawan dapat bekerja dengan penuh rasa tanggung jawab.

Sumber daya manusia merupakan asset bagi setiap perusahaan, karena terlibat langsung serta berperan aktif dalam menjalankan kegiatan perusahaan. Untuk itu perusahaan perlu memberikan perhatian secara maksimal kepada karyawannya melalui peningkatan kemampuan, pengetahuan dan keterampilan karyawan, terutama untuk menghadapi perkembangan teknologi yang demikian pesat dan persaingan yang sangat ketat. Salah satu solusi yang dapat dilakukan untuk menghadapi persaingan tersebut ialah dengan cara meningkatkan daya saing, baik dalam segi produk maupun kemampuan sumber daya karyawan mempersiapkan persaingan tersebut. Oleh karena itu perusahaan terus dituntut untuk meningkatkan seluruh aktivitasnya agar mampu bersaing dalam mempertahankan kelangsungan hidup suatu perusahaan, sehingga tujuan perusahaan akan tercapai

Perusahaan tidak cukup hanya dengan mempunyai modal besar untuk mencapai tujuannya, tetapi harus dibantu oleh karyawannya. Oleh karena itu, antara perusahaan dengan karyawan harus mempunyai kerja sama untuk mencapai tujuan yang diinginkan serta terwujud dalam produktivitas kerja. Produktivitas kerja karyawan merupakan faktor yang sangat penting dalam menunjang keberhasilan usaha. Produktivitas yang tinggi akan sangat menguntungkan, baik bagi pengusaha maupun bagi karyawan terutama untuk kesejahteran. "Produktivitas juga mencerminkan etos kerja karyawan yang tercermin juga sikap mental yang baik. Pengusaha maupun karyawan yang terlibat dalam suatu 
perusahaan harus berupaya untuk meningkatkan produktivitas" (Sulaeman, 2014). Jika Produktivitas naik ini hanya dimungkinkan oleh adanya peningkatan efisiensi (waktubahan-tenaga) dan sisitem kerja, teknik produksi dan adanya peningkatan keterampilan dari tenaga kerjanya.

Untuk dapat meningkatkan produktivitas kerja karyawan, salah satu faktornya adalah meningkatkan kemampuan karyawan melalui program pelatihan. Karyawan membutuhkan pelatihan untuk meningkatkan produktivitas kerjanya. Pelatihan (training) merupakan upaya berkelanjutan untuk meningkatkan produktivitas kerja karyawan. Pelatihan memiliki potensi untuk menyelaraskan para karyawan dengan strategi-strategi perusahaan sedangkan produktivitas kerja karyawan adalah salah satu ukuran perusahaan dalam mencapai tujuannya. Oleh karena itu, proses ini terikat dengan berbagai tujuan organisasi, pelatihan dapat dipandang secara sempit maupun luas. Secara terbatas, pelatihan menyediakan para karyawan dengan pengetahuan yang spesifik dan dapat diketahui serta keterampilan yang digunakan dalam pekerjaan mereka saat ini. Pelatihan merupakan program yang diberikan untuk menutupi kesenjangan antara kemampuan karyawan dengan tuntutan pekerjaan sehingga dapat memperbaiki prestasi kerja pada suatu pekerjaan tertentu.

Faktor lain yang dapat mempengaruhi produktivitas kerja adalah komitmen kerja karyawan. Dengan komitmen kerja dalam perusahaan yang tinggi dari setiap karyawan, akan diperoleh karyawan yang setia dan bekerja sebaik mungkin untuk kepentingan perusahaan. Keadaan ini sangat baik bagi pencapaian tujuan perusahaan, karena perusahaan mendapat dukungan penuh dari karyawannya, sehingga bisa berkonsentrasi secara penuh pada tujuan yang diprioritaskan. Komitmen kerja tersebut dapat terwujud apabila individu dalam perusahaan, menjalankan hak dan kewajiban mereka sesuai dengan tugas dan fungsinya masing-masing dalam perusahaan, karena pencapaian tujuan perusahaan merupakan hasil kerja semua karyawan perusahaan yang bersifat kolektif. Perusahaan harus memberi perhatian yang penuh dan membuat karyawan percaya terhadap perusahaan, sehingga akan diperoleh komitmen kerja karyawan dan menjadikan karyawan produktif dalam bekerja.

Setiap orang yang bekerja di suatu perusahaan, harus mempunyai komitmen dalam bekerja karena apabila suatu perusahaan karyawannya tidak mempunyai suatu komitmen dalam bekerja, maka tujuan dari perusahaan tersebut tidak akan tercapai. Namun terkadang suatu perusahaan kurang memperhatikan komitmen yang ada terhadap karyawannya, sehingga berdampak pada penurunan kinerja terhadap karyawan ataupun loyalitas karyawan menjadi berkurang

PT Jingga Langit Media bergerak di bidang hubungan masyarakat (public relation), iklan, komunikasi pemasaran, dan konsultasi hubungan media yang berspesialisasi dalam menyediakan berbagai layanan skala kecil hingga menengah kepada klien yang menekankan kepada kerja tim, kreativitas, dan ide-ide baru. Sebagai strategis bisnis mitra PT BNI Indonesia, PT Jingga Langit Media membantu dalam membuat program-program baru dan merealisasikan setiap program agar dapat terwujud.

Beberapa hal yang sudah dikerjakan oleh PT Jingga untuk BNI adalah sebagai merchant aggregator, distribusi tapcash, monitoring merchant, dan penempatan media iklan. Beberapa retail bisnis dan merchant dengan bidang yang berbeda, dan yang sudah bekerja sama adalah Prima Fresh Market, Circle K, Mini Mart, Pepito Supermarket, Coco Mart, Ramayana \& Co, Hard Rock Café, Die Stube, Youreka, Bhayangkara Football Club. Atas dasar kerjasama yang sudah dijalankan oleh beberapa mitra bisnis, PT Jingga Langit Media terus melakukan pelatihan kepada karyawan agar dapat menjaga kemampuan teknis 
sesuai dengan bidang yang diinginkan oleh para mitra bisnis yang sekaligus mengikat pada karyawan agar tetap komitmen kerja dapat dilaksanakan dengan baik.

Berdasarkan latar belakang, tujuan penelitian ini adalah untuk mengetahui pengaruh pelatihan dan komitmen kerja terhadap produktivitas kerja di PT Jingga Langit Media.

\section{LANDASAN TEORI}

\section{Produktivitas Kerja}

Pada dasarnya produktivitas kerja adalah konsep universal yang berlaku bagi semua sistem, karena setiap kegiatan memerlukan produktivitas dalam pelaksanaanya. Untuk meningkatkan produktivitas tersebut perlu adanya upaya dari perusahaan untuk meningkatkan kinerja karyawan tersebut agar hasil produktifitas yang diinginkan dapat tercapai. Dengan adanya kaitan dalam hal produktivitas kerja tersebut diperlukan adanya kepemimpinan yang baik, disiplin kerja yang tinggi, pemberian motivasi kepada karyawan agar memberikan semangat dalam bekerja, serta pemberian kompensasi yang sesuai dan tepat sasaran kepada karyawan. Suatu organisasi baik itu organisasi besar maupun kecil akan tergugah oleh pentingnya arti perbaikan tingkat produktivitas kerja.

Wartana (2011), "produktivitas kerja sebagai kemampuan seseorang untuk menghasilkan sesuatu dari tugas dan pekerjaan yang diberikan oleh perusahaan". Nawawi dalam Yuniarsih, et al (2011) mengemukakan bahwa "produktivitas kerja merupakan perbandingan antara hasil yang diperoleh (output) dengan jumlah sumber daya yang dipergunakan sebagai masukan (input)".Umar (2013), mengatakan "produktivitas ialah "perbandingan antara hasil yang dicapai (output) dengan keseluruhan sumber daya yang digunakan (input)". Hasibuan (2013), menyampaikan "produktivitas adalah "perbandingan antara output (hasil) dengan input (masukan)". Gaol (2014), mengemukakan "produktivitas kerja merupakan prestasi karyawan di lingkungan kerjanya". Dari sisi lain, produktivitas kerja merupakan pemanfaatan atau penggunaan sumber daya manusia secara efektif dan efisien. Produktivitas yang tinggi merupakan cerminan karyawan yang merasa puas akan pekerjaannya dan akan memenuhi semua kewajibannya sebagai karyawan. Produktivitas kerja adalah kemampuan karyawan dalam berproduksi dibandingkan dengan input yang digunakan, seorang karyawan dapat dikatakan produktif apabila mampu menghasilkan barang atau jasa sesuai dengan diharapkan dalam waktu yang singkat atau tepat. Dari pengertian tersebut, dapat disimpulkan bahwa produktivitas kerja merupakan kemampuan karyawan dalam berproduksi dibandingkan dengan input yang digunakan, seorang karyawan dapat dikatakan produktif apabila mampu menghasilkan barang atau jasa sesuai dengan diharapkan dalam waktu yang singkat atau tepat

Dalam upaya meningkatkan produktivitas kerja karyawan di suatu perusahaan perlu memperhatikan faktor-faktor yang mempengaruhi produktivitas kerja karyawan tersebut. Banyak faktor yang mempengaruhi produktivitas kerja karyawan baik yang berhubungan dengan tenaga kerja itu sendiri maupun faktor-faktor yang berhubungan dengan lingkungan perusahaan dan kebijakan pemerintah secara keseluruhan. Simanjuntak (2011), faktor yang mempengaruhi produktivitas kerja karyawan perusahaan dapat digolongkan pada dua kelompok, yaitu: pertama, "yang menyangkut kualitas dan kemampuan fisik karyawan yang meliputi: tingkat pendidikan, latihan, motivasi kerja, etos kerja, mental dan kemampuan fisik karyawan. Kedua, berupa sarana pendukung yang meliputi: 1) Lingkungan kerja (Produksi, sarana dan peralatan produksi, tingkat keselamatan kerja. 2) Kesejahteraan karyawan (manajemen dan hubungan industri)”. 
Simanjuntak dalam Dewi dan Aeni (2012), menyatakan bahwa "produktivitas tenaga kerja dipengaruhi oleh berbagai faktor yang berhubungan dengan tenaga kerja itu sendiri maupun yang berhubungan dengan lingkungan perusahaan dan kebijaksanaan pemerintah secara keseluruhan, seperti pendidikan, ketrampilan, disiplin, sikap dan etika kerja, motivasi, gizi dan kesehatan, tingkat penghasilan, jaminan sosial, lingkungan dan iklim kerja, hubungan industrial dan kebijaksanaan pemerintah tentang produksi, investasi, perizinan, teknologi, fiskal, harga, distribusi dan lain-lain". Faktor-faktor tersebut dapat mempengaruhi produktivitas kerja karyawan baik secara langsung tidak langsung. Produktivitas kerja juga dipengaruhi tingkat kehadiran karyawan dalam tempat kerja atau absen karyawan. Produktivitas tidak mungkin tercapai secara optimal jika tingkat kehadiran karyawan sangat rendah.

Untuk mengukur produktivitas sering kali tidak dapat dilihat dan sulit untuk diukur, menggunakan teknik-teknik pengukuran yang dapat diketahui suatu produtivitas, untuk itu akan dikemukakan beberapa cara untuk mengukur produktivitas kerja yaitu: Ilyas (2011), mengemukakan pengukuran produktivitas dengan dua cara: "physical productivity" dan "value productivity". Yang dimaksud dengan pengukuran physical productivity adalah pengukuran produktivitas secara kuantitatif dengan unit pengukuran dapat berupa ukuran, panjang, jumlah unit, berat, waktu dan jumlah sumber daya manusia, sedangkan value productivity adalah pengukuran produktivitas dengan menggunakan nilai uang sebagai tolak ukur sehingga tingkat produktivitas dikonversi kebentuk rupiah.

Produktivitas mengandung pengertian sikap mental yang selalu mempunyai pandangan "mutu kehidupan hari ini harus lebih baik dari hari kemarin, dan hari esok lebih baik dari hari ini". Sikap-sikap mental yang produktif antara lain menyangkut sikap motivatif, disiplin, kreatif, inovatif, dinamis, profesional dan berjiwa perjuangan, Sedarmayanti (2013). Dimensi dalam produktivitas ini yakni: 1) Efisiensi; terdiri dari: a) Hubungan kerja sesama bawahan, b) Hubungan kerja dengan atasan, c) Jaminan pemeliharaan kesehatan. d) Jaminan sosial ketenagakerjaan 2) Efektivitas: terdiri dari a) Etika kerja. b) Disiplin kerja. 3) Kualitas; terdiri dari: a) Kecakapan. b). Pengalaman kerja.

\section{Pelatihan}

Adanya kesenjangan antara kemampuan karyawan dengan yang dikehendaki organisasi, menyebabkan perlunya organisasi menjembatani kesenjangan tersebut, salah satunya caranya adalah melalui pelatihan. Dengan demikian diharapkan seluruh potensi yang dimiliki karyawan, yaitu pengetahuan, keterampilan dan sikap dapat ditingkatkan, akhirnya kesenjangan berkurang atau tidak terjadi bagi kesenjangan.

Mathis dan Jackson (2006), mengemukakan pelatihan adalah "suatu proses dimana orang-orang mencapai kemampuan tertentu untuk membantu mencapai tujuan organisasi". Nawawi, (2006), menyebutkan pelatihan adalah "program-program untuk memperbaiki kemampuan melaksanakan pekerjaan secara individual, kelompok dan atau berdasarkan jenjang jabatan dalam organisasi/perusahaan". Pengertian lain mengatakan pelatihan adalah proses melengkapi para pekerja dengan keterampilan khusus atau kegiatan membantu para pekerja dalam memperbaiki pelaksanaan pekerjaan yang tidak efisien. Mangkuprawira (2011), "pelatihan merupakan sebuah proses mengajarkan pengetahuan dan keahlian serta sikap agar karyawan semakin terampil dan mampu melaksanakan tanggung jawabnya dengan semakin baik, sesuai dengan standar". Mathis dan Jackson (2006), menyebutkan "pelatihan adalah "suatu proses dimana orang-orang mencapai kemampuan tertentu untuk membantu mencapai tujuan organisasi. Oleh karena itu, proses ini terikat dengan berbagai tujuan organisasi". Simanjuntak, (2011), mengemukakan 
"pelatihan merupakan bagian dari investasi sumber daya manusia (human investment) untuk meningkatkan kemampuan dan keterampilan kerja, dan dengan demikian meningkatkan kinerja karyawan". Dari pengertian tersebut, dapat disimpulkan bahwa pelatihan secara tegas dapat dipisahkan, yaitu usaha meningkatkan ketrampilan maupun pengetahuan secara teknis bagi karyawan.

Moekijat (2010), menyampaikan tujuan umum dari pada pelatihan adalah: 1) Untuk mengembangkan keahlian sehingga pekerjaan dapat diselesaikan dengan lebih cepat dan lebih efektif. 2) Untuk mengembangkan pengetahuan, sehingga pekerjaan dapat diselesaikan secara rasional. 3) Untuk mengembangkan sikap, sehingga menimbulkan kerja sama dengan teman-teman pegawai dan pimpinan". Rivai (2010) menyampaikan manfaat yang diperoleh dari latihan kerja yang dilaksanakan oleh setiap perusahaan lain: 1) "Manfaat untuk karyawan; a) Membantu pegawai dalam membuat keputusan dan pemecahan masalah yang lebih efektif. b) Membantu mendorong dan mencapai pengembangan diri dan rasa percaya diri. c) Membantu karyawan mengatasi stres, tekanan, frustasi, dan konflik. d) Meningkatkan kepuasan kerja dan pengakuan. e) Membantu pegawai mendekati tujuan pribadi sementara meningkatkan keterampilan interaksi. 2) Manfaat untuk perusahaan; a) Mengarahkan untuk meningkatkan profitabilitas atau sikap yang lebih positif terhadap orientasi profit. b) Memperbaiki pengetahuan kerja dan keahlian pada semua level perusahaan. c) Memperbaiki pegawai untuk mengetahui tujuan perusahaan. d) Meningkatkan hubungan antara atasan dengan bawahan. e) Membantu mempersiapkan dan melaksanakan kebijakan perusahaan".

Dalam rangka pelatihan, ada tiga metode yang coba dikembangkan, metode-metode tersebut sesuai dengan kondisi masyarakat dan kebutuhan pelatihan, metode-metode yang dikembangkan tersebut menurut Kamil (2010) meliputi: 1) "Mass teaching method, yakni metode yang ditunjukan pada masa. Metode ini dipilih untuk menyampaikan sampai pada taraf awareness (kesadaran) dan interest (ketertarikan). 2) Group teaching method, yakni metode yang ditunjukan pada kelompok. Metode ini dipilih untuk menyampaikan sampai pada taraf kesadaran dan ketertarikan ditambah dengan evaluation (pertimbangan) dan trial (mencoba). 3) Individual teaching method, yakni metode yang ditunjukan pada individu, dan metode ini dipilih untuk menyampaikan sampai kesadaran, ketertarikan, pertimbangan dan mencoba, juga peserta pelatihan sampai pada taraf adoption (mengambil alih), action (berbuat), dan satisfaction (kepuasan)".

Metode-metode pelatihan tersebut dipilih sesuai dengan sasaran pelatihan dan dilihat dari tujuan masyarakat (peserta pelatihan) dalam kegiatan pembelajaran karena tujuan tersebut berkaitan dengan konsep diri masyarakat dan pengalaman belajarnya. Hal tersebut akan mempengaruhi keberhasilan dalam kegiatan pembelajaran. Metode yang digunakan juga haruslah bervariasi agar dapat menumbuhkan motivasi belajar peserta pelatihan, sehingga tidak munculnya kejenuhan atau kebosanan dari peserta pelatihan dalam mengikuti kegiatan pelatihan.

Indikator pelatihan yang menurut Mangkunegara (2017), diantaranya: 1) Instruktur; Mengingat pelatih umumnya berorientasi pada peningkatan skill, para pelatih yang dipilih untuk memberikan materi pelatihan harus benar-benar memiliki kualifikasi yang memadai sesuai bidangnya, personal dan kompeten, selain itu pendidikan intruktur pun harus benarbenar baik untuk melakukan pelatihan. 2) Peserta; Peserta pelatihan tentunya harus diseleksi berdasarkan persyaratan tertentu dan kualifikasi yang sesuai, selain itu peserta pelatihan juga harus memiliki semangat yang tinggi untuk mengikuti pelatihan. 3) Materi; Pelatihan sumber daya manusia merupakan materi atau kurikulum yang sesuai dengan tujuan pelatihan sumber daya manusia yang hendak dicapai oleh perusahaan dan materi 
pelatihan pun harus update agar si peserta dapat dapat memahami masalah yang terjadi pada kondisi yang sekarang. 4) Metode; Metode pelatihan akan lebih menjamin berlangsungnya kegiatan pelatihan sumber daya manusia yang efektif apabila sesuai dengan jenis materi dan komponen peserta pelatihan. 5) Tujuan dan sasaran; Pelatihan merupakan tujuan yang ditentukan, khususnya terkait dengan penyusunan rencana aksi (action play) dan penetapan sasaran, serta hasil yang diharapkan dari pelatihan yang akan diselenggarakan, selain itu tujuan pelatihan pula harus disosialisasikan sebelumnya pada para peserta agar peserta dapat memahami pelatihan tersebut. Sasaran pelatihan harus ditentukan dengan kriteria yang terinci dan terukur (measurable)".

\section{Komitmen Kerja}

Bekerja adalah suatu bentuk aktivitas yang melibatkan kesadaran manusia untuk mencapai hasil yang sesuai dengan harapannya. Berkaitan dengan komitmen kerja karyawan, Mathis dan Jackson (2006), komitmen kerja adalah "derajat dimana karyawan mau percaya sepenuhnya, mau menerima tujuan-tujuan perusahaan serta mau untuk tetap tinggal dan tidak akan meninggalkan perusahaan dalam jangka waktu yang lama". Wibowo (2012), komitmen adalah "perasaan identifikasi, loyalitas dan keterlibatan yang ditunjukkan oleh pekerja terhadap organisasi atau unit organisasi".

Komitmen pada organisasi menyangkut tiga sikap yaitu: 1) Perasaan identifikasi dengan tujuan organisasi; 2). Perasaan keterlibatan dalam tugas organisasi; dan 3) Perasaan loyalitas untuk organisasi. Steers dan Porter (dalam Mardiana, 2010), mengemukakan komitmen terhadap organisasi sebagai "sifat" hubungan seorang individu dengan organisasi yang memungkinkan seseorang yang mempunyai keikatan yang tinggi dengan memperlihatkan keinginan kuat untuk tetap menjadi anggota organisasi atau mempertahankan keanggotaannya dalam organisasi, kesediaan untuk berusaha sebaik mungkin atau bekerja keras demi kepentingan organisasi tersebut, dan kepercayaan yang kuat dan penerimaan yang penuh terhadap tujuan dan nilai-nilai organisasi. seseorang yang memiliki komitmen kerja karyawan yang tinggi akan memiliki kemauan secara sadar untuk mencurahkan usaha demi kepentingan organisasi. Karyawan bekerja bukan karena adanya instruksi melainkan termotivasi dari dalam diri sendiri. "Komitmen organisasi merupakan derajat dimana seorang karyawan mengidentifikasikan dirinya dengan organisasi tertentu beserta tujuannya dan berkeinginan untuk mempertahankan keanggotaannya dalam organisasi tersebut" Robbins (2010). Mathis dan Jackson (2006), mengemukakan "komitmen kerja adalah "derajat dimana karyawan mau percaya sepenuhnya, mau menerima tujuan-tujuan perusahaan serta mau untuk tetap tinggal dan tidak akan meninggalkan perusahaan dalam jangka waktu yang lama". Berdasarkan hal tersebut variabel komitmen kerja secara teoritis memiliki hubungan yang erat dalam mempengaruhi produktivitas kerja karyawan.

Berdasarkan teori, karyawan yang memiliki komitmen kerja yang tinggi akan peduli terhadap pekerjaan yang diberikan kepadanya serta adanya dorongan dalam diri untuk bekerja lebih baik dengan tingkat kepuasan kerja dan disiplin yang tinggi, sehingga dapat menyediakan waktu lebih banyak untuk menyelesaikan suatu pekerjaan. Komitmen di dalam diri seseorang timbul karena adanya rasa tanggungjawab terhadap sesuatu. Sebagian orang berkomitmen karena menyukai yang dilakukannya, sedangkan sebagian orang lainnya berkomitmen karena adanya perasaan takut kehilangan sesuatu jika tidak menjalankan komitmennya. Adapun ciri-ciri komitmen adalah sebagai berikut: 1) Adanya perjanjian yang disepakati, baik terhadap diri sendiri maupun terhadap pihak lain. 2) Terdapat tujuan atau goal tertentu yang ingin dicapai setelah melaksanakan komitmen. 3) 
Semua pihak yang terlibat dalam suatu komitmen harus bertanggungjawab dengan isi perjanjian. 4) Adanya kesetiaan (loyalitas) dari semua pihak terhadap tujuan yang ingin dicapai.

Pengukuran komitmen kerja karyawan menggunakan empat indikator yang dikembangkan oleh Mowday, et al (1983) yaitu: 1) Keinginan kuat tetap sebagai anggota; Karyawan bangga bekerja di perusahaan, dan menganggap perusahaan sebagai tempat yang baik untuk bekerja. 2) Keinginan berusaha keras dalam bekerja; Adanya perasaan nyaman yang dirasakan karyawan membuat karyawan termotivasi untuk selalu berprestasi lebih baik lagi. 3) Penerimaan nilai organisasi; Karyawan merasa bahwa nilai-nilai yang diterapkan dan berlaku di perusahaan sesuai dengan nilai yang dianut oleh karyawan. 4) Penerimaan tujuan organisasi; Keinginannya untuk tetap berada di perusahaan membuat karyawan berusaha keras dalam melaksanakan tugas supaya tujuan perusahaan tercapai”.

\section{METODE PENELITIAN}

Penelitian ini menggunakan penelitian deskriptif kuantitatif. Dalam penelitian ini yang dijadikan tempat penelitian, yaitu PT Jingga Langit Media. Populasi yang digunakan dalam penelitian ini adalah seluruh karyawan PT Jingga Langit Media. Pemilihan sampel yang digunakan dalam penelitian adalah sampling jenuh, dimana semua anggota populasi dijadikan sebagai sampel, sehingga sampel dari penelitian ini sebanyak 40 responden. Sumber data dalam penelitian ini berupa data primer, yaitu data yang diperoleh langsung dari responden melalui pengisian kuesioner. Teknik analisis data yang digunakan adalah analisis regresi linier sederhana dan berganda.

\section{HASIL PENELITIAN DAN PEMBAHASAN}

\section{Hasil Penelitian}

\section{Hasil uji validitas dan uji reliabilitas}

Variabel penelitian yang terdiri dari pelatihan, komitmen kerja, dan produktivitas kerja keseluruhan memiliki 26 butir pernyataan. Validitas merupakan derajat ketepatan antara data yang terjadi pada objek penelitian dengan data yang dapat dilaporkan oleh peneliti. Uji validitas digunakan untuk mengukur yang dapat dikatakan sah atau tidaknya suatu kuesioner (Sugiyono, 2016). Berdasarkan uji validitas terdapat 10 butir pertanyaan untuk pelatihan, 8 butir pertanyaan untuk komitmen kerja, dan 8 pertanyaan butir untuk produktivitas kerja dengan hasilnya dinyatakan valid.

Pengujian reliabilitas digunakan untuk menguji seberapa jauh hasil pengukuran yang dapat diandalkan secara konsisten. Pada tabel-1, menunjukkan bahwa nilai Cronbach's Alpha semua variabel dalam penelitian ini lebih besar dari 0,6 , sehingga penelitian ini dapat dianggap reliabel.

Tabel 1: Hasil Uji Reliabilitas Variabel

\begin{tabular}{lcc}
\hline \multicolumn{1}{c}{ Variabel } & Cronbach's Alpha & Keterangan \\
\hline Pelatihan & 0.745 & Reliabel \\
Komitmen Kerja & 0.604 & Reliabel \\
Produktivitas Kerja & 0.679 & Reliabel \\
\hline
\end{tabular}




\section{Hasil analisis regresi linear berganda}

Berdasarkan tabel-2, F-hitung sebesar 59,510, artinya secara bersama-sama pelatihan dan komitmen kerja berpengaruh signifikan pada tingkat nyata $99 \%$ terhadap produktivitas kerja karyawan PT. Jingga Langit Media. Nilai koefisien determinasi $\left(\mathrm{R}^{2}\right)$ sebesar 0.763 , artinya variabel pelatihan dan komitmen kerja memberikan kontribusi sebesar $76,3 \%$ kepada variabel produktivitas kerja karyawan PT. Jingga Langit Media, sedangkan sisanya sebesar 23,7\% disumbangkan faktor lain yang tidak dibahas dalam penelitian ini.

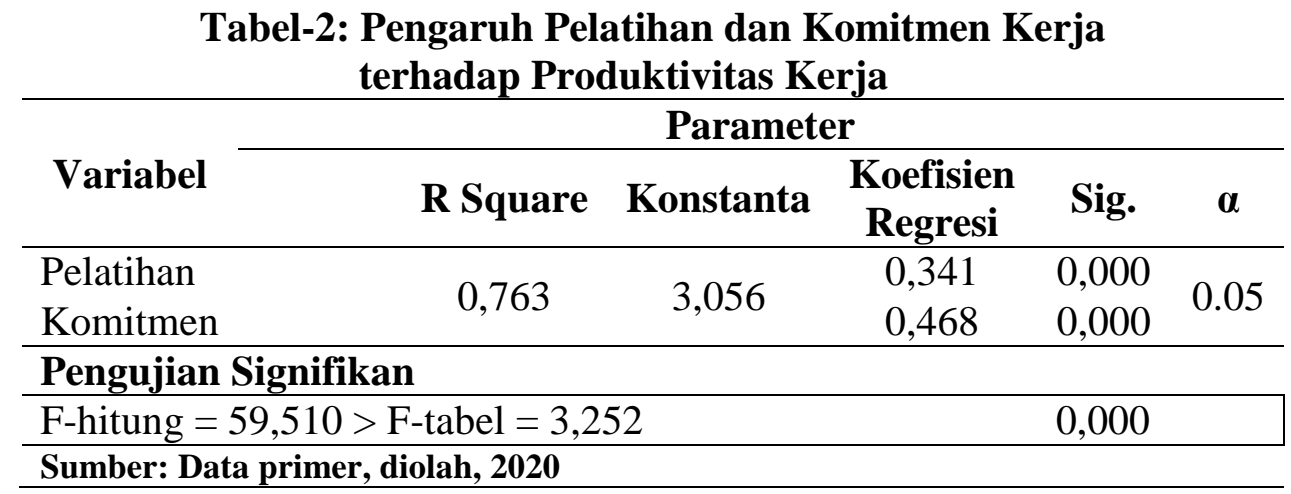

Persamaan regresi: $\mathrm{Y}=3,056+0,341 \mathrm{X}_{1}+0,468 \mathrm{X}_{2}$

Pelatihan dan komitmen kerja berpengaruh positif dan signifikan terhadap produktivitas kerja karyawan PT. Jingga Langit Media, pada tingkat nyata 95\%. Koefisien pelatihan sebesar 0,341, artinya jika ada peningkatan pelatihan, maka produktivitas kerja karyawan PT. Jingga Langit Media akan meningkat atau sebaliknya dengan asumsi komitmen kerja tidak berubah. Koefisien komitmen kerja sebesar 0,468, artinya jika ada peningkatan komitmen kerja, maka produktivitas kerja karyawan PT. Jingga Langit Media akan meningkat atau sebaliknya, dengan asumsi pelatihan tidak berubah, hipotesis pertama diterima

\section{Hasil analisis regresi linear sederhana}

Tabel-3: Pengaruh Pelatihan Terhadap Produktivitas Kerja

\begin{tabular}{lccccc}
\hline \multirow{2}{*}{ Variabel } & R-Square & Konstanta & $\begin{array}{c}\text { Koefisien } \\
\text { Regresi }\end{array}$ & Sig & $\boldsymbol{\alpha}$ \\
\cline { 2 - 6 } & 0,659 & 8,187 & 0,578 & 0,000 & 0.05 \\
\hline Pelatihan & & & & \\
\hline Pengujian Signifikan & & & \\
\hline t-hitung $=8,571>$ t-tabel $=2,024$ & & \\
\hline Sumber: Data primer, diolah, 2020 &
\end{tabular}

Persamaan regresi: $\mathrm{Y}=8,187+0,578 \mathrm{X}_{1}$

Berdasarkan Tabel-3, nilai koefisien determinasi $\left(\mathrm{R}^{2}\right)$ sebesar 0.659 , artinya pelatihan memberikan kontribusi sebesar $65,9 \%$ terhadap produktivitas kerja karyawan PT. Jingga Langit Media, sedangkan sisanya sebesar 34,1\% disumbangkan faktor lain. Pelatihan berpengaruh positif terhadap produktivitas kerja karyawan PT. Jingga Langit 
Media. Koefisien pelatihan sebesar 0,578, artinya jika ada peningkatan pelatihan, maka produktivitas kerja karyawan PT. Jingga Langit Media akan meningkat atau sebaliknya. Nilai t-hitung $=8,571>$ t-tabel $=2,024$, Ho tolak, Ha terima, artinya ada pelatihan berpengaruh signifikan pada tingkat nyata $99 \%$ terhadap produktivitas kerja karyawan PT. Jingga Langit Media, hipotesis kedua diterima.

Tabel-4: Pengaruh Komitmen Kerja Terhadap Produktivitas Kerja

\begin{tabular}{lccccc}
\hline \multirow{2}{*}{ Variabel } & R-Square & Konstanta & $\begin{array}{c}\text { Koefisien } \\
\text { Regresi }\end{array}$ & Sig & $\boldsymbol{\alpha}$ \\
\cline { 2 - 6 } & 0,651 & 5,778 & 0,816 & 0,000 & 0.05 \\
\hline Komitmen & Pengujian Signifikan & & & \\
\hline t-hitung = 8,422 $>$ t-tabel $=2,024$ \\
\hline Sumber: Data primer, diolah, 2020 \\
\hline
\end{tabular}

Persamaan regresi: $\mathrm{Y}=5,778+0,816 \mathrm{X}_{2}$

Berdasarkan tabel-4, nilai koefisien determinasi $\left(\mathrm{R}^{2}\right)$ sebesar 0.651 , artinya komitmen kerja memberikan kontribusi sebesar $65,1 \%$ terhadap produktivitas kerja karyawan PT. Jingga Langit Media, sedangkan sisanya sebesar 34,9\% disumbangkan faktor lain. Komitmen kerja berpengaruh positif terhadap produktivitas kerja karyawan PT. Jingga Langit Media. Koefisien komitmen kerja sebesar 0,816, artinya jika ada peningkatan komitmen kerja, maka produktivitas kerja karyawan PT. Jingga Langit Media akan meningkat atau sebaliknya. Nilai t-hitung $=8,422>\mathrm{t}$-tabel $=2,024$, maka Ho tolak, Ha terima, artinya komitmen kerja berpengaruh signifikan pada tingkat nyata $99 \%$ terhadap produktivitas kerja karyawan PT. Jingga Langit Media, hipoteis ketiga diterima.

\section{Pembahasan}

\section{Pengaruh pelatihan dan komitmen terhadap produktivitas kerja karyawan}

Peningkatan pelatihan dan komitmen mendukung peningkatan produktivitas kerja karyawan PT. Jingga Langit Media. Hasil penelitian ini sama dengan hasil penelitian yang dilakukan Bakri, et al, (2014), dan Pratono, et, al (2017), yang menyatakan bahwa pelatihan dan komitmen kerja berpengaruh terhadap produktivitas kerja karyawan.

\section{Pengaruh pelatihan terhadap produktivitas kerja karyawan}

Peningkatan pelatihan mendukung peningkatan produktivitas kerja karyawan PT. Jingga Langit Media. Hal ini menunjukkan bahwa instruktur pelatihan memiliki kualifikasi sesuai dengan bidangnya, harus benar-benar baik memberikan pelatihan, peserta sudah diselekasi sesuai klasifikasi, memiliki semangat mengikuti pelatihan, materi pelatihan sesuai yang hendak dicapai perusahaan, harus update sesuai kondisi sekarang, metode sesuai jenis pelatihan, dan sesuai komponen peserta pelatihan, hasil pelatihan dapat meningkatkan ketrampilan karyawan, dan sasaran pelatihan harus terukur berdaarkan kriteria. Hasil penelitian ini sejalan dengan penelitian yang dilakukan oleh Pradasari, et, al 
(2016), dan Gumilar, (2018), yang menyatakan bahwa pelatihan berpengaruh terhadap produktivitas kerja karyawan.

\section{Pengaruh komitmen terhadap produktivitas kerja karyawan}

Peningkatan komitmen mendukung peningkatan produktivitas kerja karyawan PT. Jingga Langit Media. Hal ini dikarenakan bahwa karyawan merasa bangga bekerja diperusahaan ini, perusahaan dianggap sebagai tempat yang baik untuk bekerja, adanya perasaan nyaman dalam bekerja, termotivasi untuk selalu berprestasi lebih baik lagi, merasakan nilai-nilai yang diterapkan sudah sesuai seperti yang dianutnya, karyawan merasa betah untuk tetap berada diperusahaan dan berusahan keras dalam melaksanakan tugasnya. Hasil penelitian ini sejalan dengan hasil penelitian yang dilakukan Marsoit, et, al (2017) yang menyatakan bahwa komitmen berpengaruh terhadap produktivitas kerja karyawan.

\section{KESIMPULAN DAN SARAN}

\section{Kesimpulan}

Kesimpulan dalam penelitian ini adalah sebagai berikut; 1) Pelatihan mendukung peningkatan produktivitas kerja karyawan PT. Jingga Langit Media. 2). Komitmen mendukung peningkatan produktivitas kerja karyawan PT. Jingga Langit Media. 3). Pelatihan dan komitmen kerja secara bersama-sama mendukung peningkatan produktivitas kerja karyawan PT. Jingga Langit Media.

\section{Saran}

Saran atau rekomendasi dalam penelitian ini adalah sebagai berikut: 1) Pelatihan yang terdapat di PT. Jingga Langit Media sudah cukup baik, namun demikian untuk lebih meningkatkan produktivitas kerja karyawan kedepan diberikan pelatihan yang rutin agar karyawan terus dapat mengembangkan ketrampilannya dari hasil mengikuti pelatihan dan ini tentunya harapan dari perusahaan. 2) Komitmen yang terdapat di PT. Jingga Langit Media sudah baik, ini terlihat dari para karyawan yang merasa memiliki perusahaan tersebut dan enggan untuk berhenti dari perusahaan ini, tentunya untuk lebih lagi menjaga komitmen karyawan kedepan maka perhatikan apa yang menjadi keinginan dan kebutuhan karyawan, sehingga karyawan merasa betah bekerja di PT. Jingga Langit Media. 3). Bagi penelitian selanjutnya disarankan untuk menambah variabel-variabel lain dalam menganalisis faktor-faktor yang mempengaruhi produktivitas kerja karyawan agar lebih baik.

\section{DAFTAR PUSTAKA}

Bakri, Muhammad., Nuryanti dan Pramadewi, Arwinence. 2014. Pengaruh Komitmen Karyawan dan Pelatihan terhadap Produktivitas Kerja Karyawan Departemen Pelayanan PT. PLN (Persero) Cabang Selatpanjang Kabuipaten Kepulauan Meranti”. JOM FEKOM 1. No. 2 Oktober 2014. Hal. 1-15

Dewi, P. I., dan Aeni, N. (2012). Pengaruh Disiplin Kerja terhadap Produktivitas Pegawai pada Rutan Klas 1 di Bandar Lampung. Jurnal Organisasi dan Manajemen, 2(2), 8595.

Gaol, L. Jimmy. 2014. Manajemen Sumber Daya Manusia. Jakarta. Grasindo. 
Gumilar, Gugum. 2018. Pengaruh Pelatihan terhadap Peningkatan Produktivitas Kerja Karyawan PT. Raya Sugarindo Inti Tasikmalaya”. Jurnal Ilmiah Manajemen dan Bisnis, Vol. 19 No. 1, 2018, 55-63. DOI: http://doi.org/10.30596/jimb.v19i1.1804.

Hasibuan, S.P Malayu. 2013. Manajemen Sumber Daya Manusia. Jakarta. PT Bumi Aksara.

Ilyas, Yaslis. 2011. Kinerja, Teori, Penilaian dan Pelatihan. Jakarta. BP FKUM UI.

Kamil, Mustofa. 2010. Model Pendidikan dan Pelatihan (Konsep dan Aplikasi). Bandung. Alfabeta.

Mangkunegara, AA. Anwar Prabu. 2017. Manajemen Sumber Daya Manusia Perusahaan. Bandung. Rosda.

Mangkuprawira, S.Tb., 2011. Manajemen Sumber Daya Manusia Strategik. Bogor. Ghalia Indonesia.

Mardiana. 2010. Manajemen Produksi. Jakarta. IPWI.

Marsoit, Pingkan., Sendow, Greis dan Rumokoy, Farlane. 2017. Pengaruh Pelatihan, Disiplin Kerja dan Komitmen Organisasi Terhadap Kinerja Karyawan PT. Asuransi Jasa Indonesia. Jurnal EMBA. Vol. 5 No. 3 September 2017. Hal. 4285-4294. ISSN 2303-1174.

Mathis, R.L. dan J.H. Jackson. 2006. Human Resource Management: Manajemen Sumber Daya Manusia. Terjemahan Dian Angelia. Jakarta. Salemba Empat.

Moekijat, 2010, Manajemen Sumber Daya Manusia, Cetakan Kesembilan. Bandung: Mandar Maju.

Mowday, R.T., R.M. Steers \& I. W. Porter. (1983). The Measurement of Organizational Commitment. Journal of Applied Psychology. Vol.84, p.408-414.

Nawawi, Hadari. 1990. Administrasi Personil: Untuk Peningkatan Produktivitas Kerja. Jakarta. Haji Masagung.

Nawawi, Hadari. 2006. Manajemen Kinerja. Gajah Mada University Press, Yogyakarta.

Pradasari, Made Desira., Bagia, I Wayan dan Susila, Gede Putu Agus Jana. 2016. Dampak Pelatihan Terhadap Produktivitas Kerja Karyawan Pada Perusahaan. e-Journal Bisma Universitas Pendidikan Ganesha Jurusan Manajemen. Volume 4 Tahun 2016.

Pratono, Beni., Poniwati, Asmie dan Rahmasari, Anggraeni. 2017. Komunikasi, Pelatihan Kerja dan Komitmen Karyawan terhadap Kinerja Karyawan pada PT. United Indo Nissan Jemursari Surabaya". Jurnal Manajemen Branchmark. Vol. 3 Issue 3, 2017. Hal: 108-124.

Rivai, Veithzal. 2010. Manajemen Sumber Daya Manusia untuk Perusahaan dari Teori ke Praktik. Jakarta. Raja Grafindo Persada

Robbins, Stephen P. 2010. Perilaku Organisasi. Jakarta. Salemba Empat.

Sedarmayanti. 2013. Sumber Daya Manusia dan Produktivitas Kerja. Jakarta: Mandar Maju.

Simanjuntak, Payaman J. 2011.Manajemen Evaluasi Kinerja. Edisi 3. Jakarta. Fakutas UI.

Steers, R.M \& Porter, L.W. 1983. Motivation and Work Behavior, New York. Acadaemic Press.

Sugiyono. 2016. Statikstika untuk Penelitian. Bandung. Alfabeta.

Sulaeman, Ardika. 2014. Pengaruh Upah dan Pengalaman Kerja terhadap Produktivitas Karyawan Kerajinan Ukiran Kabupaten Subang, Jurnal Ekonomi Trikonomika Volume 13, No.1, Hal 91-100 ISSN 1411-514 X (print)/ISSN 23557737 (online).

Umar, Husein. 2013. Riset Sumber Daya Manusia Dalam Organisasi. Jakarta. Gramedia Pustaka Utama. 
Wartana, I. M. (2011). Faktor-Faktor yang Mempengaruhi Produktivitas Kerja Karyawan pada Como Shambala Estate at Begawan Giri Ubud Bali. Jurnal Perhotelan dan Pariwisata, 1(01), 14-34.

Wibowo. 2012. Manajemen Kinerja. Edisi Ke-3. Jakarta. Rajawali Pers.

Yuniarsih Tjuju dan Suwanto. 2011. Manajemen Sumber Daya Manusia. Bandung. Alfabeta. 